\title{
A STUDY INTO STRUCTURAL EFFECTS OF MUTUAL INVESTMENT INDUCTION IN SECTORAL ECONOMIC SYSTEMS
}

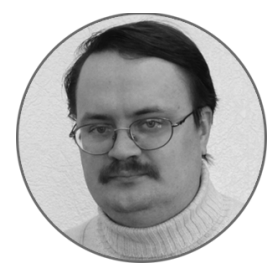

Vladimir N. MYAKSHIN

Northern (Arctic) Federal University named after M.V. Lomonosov, Arkhangelsk, Russian Federation

mcshin@yandex.ru

\section{Article history:}

Received 7 February 2017

Received in revised form 1 March 2017

Accepted 31 March 2017

Translated 3 July 2017

Available online 15 September 2017

JEL classification: D92, L50, L52, L90

\section{Abstract}

Importance As mutual relations and the effect of cross-sectoral financial flows shall be taken into account, new approaches need to be designed to study cross-sectoral investment and structural interactions through the mechanism of mutual investment induction and its structural effects. The article focuses on mutual investment induction as an economic phenomenon and respective structural effects in sectoral economic systems.

Objectives The research identifies evident patterns of investment relations in sectoral economic systems arising from the mechanism of mutual investment induction and structural effects.

Methods The methodological framework includes general scientific methods, i.e. scientific abstraction, analysis, synthesis, generalization, and systems and dialectical approaches. Data analysis is based on the methods of economic statistics (structural and dynamic analysis) and economic mathematics (methods of cross-sectoral balance) and the method of expert assessment.

Results I prove the existence of the cause-and-effect relationship and patterns seen in arising structural effects of mutual investment induction. I also elaborate theoretical principles of structural effects of mutual investment induction, proposed a set of indicators for gauging them, determine the economic substance of the indicators, devise an assessment algorithm, and technique to evaluate the entire amount of mutual investment induction in Keywords: mutual investment induction, line with its structural effects. structural effects, marginal rate, economic system, investment substitution, investment relations investment relations among adjacent industries, forecast investment processes and structural changes in sectoral economic systems and formulate investment policies subsequently.

๑) Publishing house FINANCE and CREDIT, 2017

The editor-in-charge of this article was Irina M. Komarova

Authorized translation by Irina M. Komarova

The potential production output is possible to enhance only if substantial investment is injected into the fixed capital of priority industries, as a result of growth in the investment attractiveness of sectoral economic systems.

${ }^{\dagger}$ For the source article, please refer to: Мякшин В.Н. Исследование структурных эффектов инвестиционной самоиндукции в отраслевых экономических системах. Финансовая аналитика: проблемы и решения. 2017. Т. 10. Вып. 6. С. 631-646. URL: https://doi.org/10.24891/fa.10.6.631
Having performed a structural and dynamic analysis of various investment processes by sector and tenet of the systems approach, I figure out that the existing investment potential is insufficiently utilized, thus indicating the low efficiency of the State-Business relations [1]. The level of investment, its purpose and structure fail to satisfy the real sector's needs in the innovative refurbishment of the potential production capabilities. Investment resources are 
mainly concentrated within export and natural resource processing enterprises. It obstructs the development of the real economy to a certain extent [2].

Short-term interests of the Russian and foreign investors cause so uneven allocation of investment, since investors tend to those types of economic activities that have high capital turnover and payback. Innovative industries, including processing ones, see insignificant investment indeed. It means that investors have little motivation, and contravenes the current global trends showing that knowledge-intensive production lures investors most [3].

The transition to the market economy modifies ownership and property relations. It is revealed through structural and dynamic changes in the investment process seen in various ownership forms [4].

Whereas the period of reforms saw a drastic rearrangement in the profile of economic agents that made investment decisions, the structure of financial sources of fixed capital investment changed as well. Before 1990, the public sector financed $3 / 4$ of all investment and entities' equity accounted for about 20-25 percent. Currently, budgets of all levels provide no more than 25 percent of investment. Nowadays the equity and extra-budgetary funds account for 64 percent, i.e. the proportion became almost reverse [5]. Hence, private investors play the leading role in shaping the investment process and its specifics.

Whereas the investment process is predominantly financed with non-governmental sources, it is reasonable to incentivize private investors. It becomes the main reason for regulating the investment and structural interactions in sectoral economic systems $[6,7]$.

Considering the systemic nature of this matter, its relation to macroeconomic and structural policies, the Russian economy can be modernized provided that there will be an effective mechanism for financing the investment process and regulating cross-sectoral interactions of investment and structures $[8,9]$.

This paper presents the outcome of a study into the structural effects of mutual investment induction on the basis of my own theoretical principles.
The sectoral economic system stands for types of economic activities that have production-based links and result from mutual investment induction.

Investment and structural interactions mean
cross-sectoral interactions arising during the investment process and influencing the sectoral structure of the ultimate product.

Regulating the investment and structural interactions refers to a set of techniques to influence priority types of economic activities leading to co-investment in mutually related industries.

Investment and structural constructs are characterized with such key economic categories as mutually induced investment, mutual investment induction, mutual investment induction mechanism, key points of investment growth, structural effects of mutual investment induction.

The economic substance of mutual investment induction is that an additional demand for investment or a structural effect emerges in related industries as investing activities intensify in priority types of economic activities (key points of investment growth).

Mutually induced investment means additional investment resulting from a growth in investment needs in related industries after the inducing industry attracts investment. Mutually induced investment constitutes contributions that are made to create new production capacity, or structurally modify the process of creating ultimate product [10].

My approach to studying the processes of mutual investment induction includes methodological principles of the mutual investment induction mechanism, conceptual framework for identifying this phenomenon (mutual investment induction, mutually induced investment, mutual investment induction mechanism, key points of investment growth), set of indicators (coefficient of mutual investment induction, integral coefficient of mutual investment induction, multirator $\left.^{*}[11]\right)$ to gauge mutual investment induction. My previous papers cover all these concepts and indicators ${ }^{1}$.

\footnotetext{
* Translator's note: The term derived from multirate, coined by the author.

${ }^{1}$ Myakshin V.N. [Regulation of the investment structural interaction among sectors: Outlining a methodological approach]. Digest Finance, 2016, no. 3, pp. 23-37. (In Russ.)
}

Please cite this article as: Myakshin V.N. A Study into Structural Effects of Mutual Investment Induction in Sectoral Economic Systems. 
Mutual investment induction ${ }^{2}$ subsequently generates mutually induced investment and the structural effect of mutual investment induction that builds up as a phenomenon of mutually induced investment compensated with changes in the structure and volume of ultimate product.

To examine the structural effect of mutual investment induction and assess the total mutual investment induction in line with the structural effects, I propose a set of indicators. Their economic substance and assessment algorithm are given in Table 1. The assessment is based on the cross-sectoral balance method [12-15].

Having analyzed the extensive corpus of official data pertaining to the Federal State Statistics Service, Bureau of Economic Analysis at the U.S. Department of Commerce, materials of certain researches into industries of the Arkhangelsk Oblast (Russia), I prove the existence of the cause-and-effect relations and patterns of the structural effect of mutual investment induction. I also investigated the consequences of structural changes in the industries as a result of mutual investment induction. Those changes imply that mutually induced investment can be offset by changes in the sectoral structure of the economy.

To estimate the absolute value of a probable structural effect in each industry, I assess the marginal rate of investment substitution, i.e. a measure of the interchangeability of ultimate product and mutually induced investment. This indicator shows how many measurement units of ultimate product in the $i$-industry in monetary terms account for a unit of substitutable mutually induced investment in fixed assets of the $j$-industry:

$$
\operatorname{MRIS}_{i j}=-\frac{\Delta F U_{i j}}{\Delta I_{j}},
$$

where $\triangle F U_{i j}$ stands for a change in ultimate product of the $i$-industry, where the structural effect of mutual investment induction originates as a result of investment in the $j$-industry;

$\Delta I_{j}$ stands for a change in mutually induced investment in the inducing $j$-industry instigating mutual investment induction.

\footnotetext{
${ }^{2}$ Ibid.
}

Table 2 presents the assessment of the marginal rate of investment substitution for sectoral economic systems of the USA for 2013.

To evaluate structural changes in an economic system as a result of the structural effect of mutual investment induction, I suggest using elasticity indicators:

- elasticity indicator of ultimate product structure as a result of investment represents a coefficient reflecting the relative change in ultimate product in case

of the structural compensation of mutually induced investment:

$$
\begin{aligned}
& E_{i j}^{F U}=\frac{\Delta F U_{i j}}{\Delta F A_{j}} \cdot \frac{F A_{j}}{F U_{i}}=\frac{-M R I S_{i j} \cdot \Delta F A_{j}}{\Delta F A_{j}} \cdot \frac{F A_{j}}{F U_{i}}= \\
& =-\operatorname{MRIS}_{i j} \cdot \frac{F A_{j}}{F U_{i}},
\end{aligned}
$$

where $\triangle F U_{i j}$ stands for a change in the amount of ultimate product as a result of the structural compensation;

$M R I S_{i j}$ stands for the marginal rate of investment substitution;

$\Delta F A_{j}$ stands for a change in the amount of fixed assets that triggers mutual induction and the structural effect;

$F A_{j}$ stands for the value of fixed assets;

$F U_{i}$ stands for the amount of ultimate products;

- elasticity indicator of the structure of idle production capacity as a result of investment. It reflects the relative change in idle production capacity in case of the structural compensation of mutually induced investment:

$$
E_{i j}^{F C U}=\frac{\Delta F C U_{i}}{\Delta F A_{j}} \cdot \frac{F A_{j}}{F C U_{i}},
$$

where $\triangle F C U_{i}$ is a change in idle production capacity due to structural compensation;

$\Delta F A_{j}$ is a change in fixed assets that instigates mutual induction and the structural effect;

$F A_{j}$ is the value of fixed assets;

Please cite this article as: Myakshin V.N. A Study into Structural Effects of Mutual Investment Induction in Sectoral Economic Systems. 
$F C U_{i}$ is the amount of idle production capacity.

To assess potential structural changes in the economic system due to the structural effect of mutual investment induction, I propose such indicators as coefficients of investment pressure on the sectoral structure of ultimate product and structure of unutilized production capacity.

The following formula below is used to compute the coefficient of investment pressure on the sectoral structure of ultimate product. It shows how many percentage points of product output in the $i$-industry change due to the structural effect given a unit cost of mutually induced investment is compensated in the $j$-industry:

$$
K_{I P i j}=\frac{M R I S_{i j}}{F U_{i}} \cdot 100 \%,
$$

where MRIS $_{i j}$ is the marginal rate of investment substitution between the $i$-industry and $j$-industry;

$F U_{i}$ is the volume (in monetary terms) of ultimate product in the $i$-industry where the structural effect takes place.

The following formula is used to compute the coefficient of investment pressure on the structure of idle production capacity. It reflects how many percentage points of idle production capacity in the $i$-industry change due to the structural effect given a unit cost of mutually induced investment is compensated in the $j$-industry:

$$
K_{C U P i j}=\frac{M R I S_{i j}}{F C U_{i}} \cdot 100 \%,
$$

where $M R I S_{i j}$ is the marginal rate of investment substitution between the $i$-industry and $j$-industry;

$F C U_{i}$ is the volume (in monetary terms) of idle production capacity in the $i$-industry, where the structural effect of mutual investment induction takes place.

To assess the total mutual investment induction in line with its structural effects, it is necessary to add coefficients of investment pressure on the sectoral structure of gross product and the structure of production capacity.
The following formula below is used to compute the coefficient of investment pressure on the sectoral structure of gross product. It reflects how many percentage points of gross product output change in the $j$-industry due to mutual investment induction given a unit cost of mutually induced investment is incurred in the $i$-industry:

$$
K_{I i j}=\frac{M R I S_{i j}}{I_{i}} \cdot 100 \%,
$$

where $M R I S_{i j}$ is the marginal rate of investment substitution between the $i$-industry and $j$-industry;

$I_{i}$ is the volume (in monetary terms) of the gross product in the $i$-industry where mutually induced investment is made.

The following formula below is used to compute the coefficient of investment pressure on the structure of production capacity. It reflects how many percentage points of production capacity in the $j$-industry change due to the structural effects given a unit cost of mutually induced investment is incurred in the $i$-industry:

$$
K_{C U i j}=\frac{M R I S_{i j}}{C U_{i}} \cdot 100 \%,
$$

where $M R I S_{i j}$ is the marginal rate of investment substitution between the $i$-industry and $j$-industry;

$C U_{i}$ is the volume (in monetary terms) of production capacity in the $i$-industry, where mutually induced investment is made.

Mutually induced investment and structural effects of mutual investment induction spring from the mutual investment induction mechanism. It is implausible to assume that there will be mutually induced investment or the structural effect only as a result of a very improbable concurrence of circumstances.

To assess the total mutual investment induction, I assume that, the more the ultimate product structure should be changed to offset mutual investment induction, the less the probable structural effect is, in comparison with changing the structure of the gross product in the same industry during mutual investment induction. 
Total mutual investment induction shall be defined as a combination of mutually induced investment and structural effects. Thus, mutually induced investment will be higher than that assessed using integral coefficients of mutual investment induction (CMII).

Considering the structural effect, integral CMII are computed with the proportion of mutually induced investment and structural effects.

The operational intensity of production capacity is important for assessing the total mutual investment induction. To determine how much the structural effect of production capacity contributes to offsetting mutual investment induction, the structural effect is assumed to be less probable if the structure of production capacity in the industry is to be changed to a greater extent to offset mutual investment induction in comparison with changing the structure of production capacity in the same industry during mutual investment induction (contributions always imply an increase in production capacity).

Analyzing an impact of idle production capacity on mutual investment induction, it is necessary to deny the assumption that idle production capacity means the ineffective use of capital [16]. In my opinion, idle production capacity constitutes a non-monetary form of savings. That is why they cannot be arbitrarily directed to offset mutual investment induction $[17,18]$.

Total mutual investment induction linking the $i$-industry and $j$-industry, in line with the structural effect by sector ( $\left.C M I I_{\mathrm{TTL} i j}\right)$, can be estimated as CMII multiplied by coefficients of structural compensation for idle production capacity and the ultimate product output:

$$
C M I I_{\mathrm{TTL} i j}=C M I I_{i j} \cdot K_{F I}^{i} \cdot K_{C U F}^{i},
$$

where $C M I I_{i j}$ is the value of CMII regarding related $i$ - and $j$-industries, net of the structural effect;

$K_{F I}^{i}$ is the coefficient of structural compensation for ultimate product of the $i$-industry;

$K_{C U F}^{i}$ is the coefficient of structural compensation for idle production capacity in the $i$-industry.

The assessment of coefficients of structural compensation poses another separate question. While addressing it, I suggest assuming that the structural effect is proportionate to the extent to which the ultimate product structure in each industry is changeable against the gross product of the industry [19]. The changeability can be measured with the mean square deviation of ultimate product and idle production capacity for an 11-year period, according to the Juglar cycle theory.

The coefficient of structural compensation is the difference between a unit and the amount of the mean square deviation.

Structural compensation is a particular case of structural effects of mutual investment induction. Structural compensation for ultimate product implies that fixed assets of the $i_{1}$-industry are reallocated from the ultimate product output to the production of resources needed to ensure an increment in the ultimate product output in the $i_{2}$-industry as a result of investment made in the $i_{1}$-industry and higher production volumes.

In this case, the expected increase in investing activity in the $i_{1}$-industry is offset by structural changes in the ultimate product output in the $i_{1}$-industry.

If the ultimate product output changes in the $i_{1}$-industry, it may completely offset mutual investment induction. It may happen so that the ultimate product output will decrease in the receiving industry instead of the expected increase in investing activity.

Considering the economic logic of structural effects as a phenomenon, the structural compensation for ultimate product may lead only to a decrease in the ultimate product output in the receiving industry, i.e. the elasticity of ultimate product in relation to mutually induced investment is negative within the limits of the structural effect.

Structural compensation for the idle production capacity constitutes an increase in the use of production capacity, involvement of non-utilized fixed assets of the $i_{1}$-industry into the process of producing the resources that ensure an increment of the ultimate product output in the $i_{2}$-industry as a result of investment in the $i_{1}$-industry and increase in production volumes in the latter. 
In this case, the expected increase in investing activity in the $i_{1}$-industry can be offset by structural changes in idle production capacity of the $i_{1}$-industry. If idle production capacity is more utilized in the $i_{1}$-industry, it may completely offset mutual investment induction. The usage of production capacity may happen to intensify instead of the expected growth in investing activity, but the ultimate product output will still remain unchanged.

I believe the two phenomena lay the basis for the phenomenon of structural effects of mutual investment induction.

It is difficult to forecast which industry reduces its ultimate product output due to the fact that some of necessary resources in the $i_{1}$-industry are allocated for increasing the ultimate product output of the inducing $i_{2}$-industry.

There is no linear correlation in this respect. In theory, resources can be withdrawn from any industry, which effectuates its production process using resources manufactured in the industry experiencing the effect of mutual investment induction.

I reckon any economic structure strives to preserve its dimensions. While assessing the structural effects, I, therefore, adhere to the principle of minor changes. However, it is no doubt than structural effects can become large-scale and steer the development trajectory of sectoral structures.

Such elements as $C M I I_{i j}$ and the total value $C M I I_{\text {TTL } i j}$ form a matrix that characterizes the level of mutual investment induction as assessed for industries. This algorithm is certainly not a final and exhaustive solution to the issue of assessing the total amount of integral $C M I I_{\mathrm{TTL} i}$ in line with the structural effect, but rather becomes a starting point in addressing this issue. Determining the vector of the total value of integral $C M I I_{\mathrm{TTL} i}$ is the subject of another detailed research.

Table 3 indicates the amount of integral coefficients of mutual investment induction ICMII $\mathrm{TTL} j$ assessed in line with the structural effect and the proposed technique for the U.S. industries within 1997-2013.
An analysis of the given data results in the conclusions below.

Structural effects of mutual investment induction and their effect reduced integral coefficients. However, the industries still remain in the same groups (points of investment growth, key points of investment growth, types of economic activities with the medium and low level of mutual investment induction) [10].

The following industries may still be referred to as points of investment growth:

- construction - 4.12;

- wholesale trade - 1.92;

- professional and business services - 1.79;

- educational services, health care, and social assistance -1.41 ;

- manufacturing - 1.35;

- arts, entertainment, recreation, accommodation, and food services - 1.3;

- other services, except government - 1.22;

- retail trade $-1,17$.

The following industries can be considered as key points of investment growth:

- construction - 4.12;

- wholesale trade - 1.92;

- professional and business services - 1.79;

- educational services, health care, and social assistance -1.41 ;

- manufacturing - 1.35 .

The low level of mutually induced investment is detected in the following types of economic activities:

- transportation and warehousing - 0.87;

- agriculture, forestry, fishing, and hunting - 0.69;

- information - 0.51;

- government - 0.18;

- mining - 0.14; 
- utilities - 0.14;

- finance, insurance, real estate, rental, and leasing 0.07 .

Based on the findings, I conclude that the inducing industry, which has the highest integral CMII net of the structural effect, remains the key point of investment growth even if a correlation among integral coefficients of mutual investment induction changes in assessing the total integral coefficient of mutual investment induction. The reason is that the inducing industry having the highest integral CMII anyway has the strongest effect on the industries it cooperates with, whether through mutually induced investment or structural changes.

Under certain circumstances (changes in the market situation, novelties, price shocks, etc.), structural effects may grow stronger, thus significantly influencing the development of sectoral economic systems, in particular, and the national economy, as a whole [20].

The proposed set of indicators provides public administration authorities with an investment planning tool in sectoral economic systems, allows controlling the process of sectoral finance reallocation driven by the economic mechanism of mutual investment induction. 
Table 1

A set of indicators to study the structural effect of mutual investment induction

\begin{tabular}{|c|c|c|}
\hline Indicator & Mathematical formula & Computational technique \\
\hline $\begin{array}{l}\text { The marginal rate of } \\
\text { investment substitution }\end{array}$ & $M R I S_{i j}=-\frac{\Delta F U_{i j}}{\Delta I_{j}}$ & $\begin{array}{l}\text { The ratio of change in ultimate product of } \\
\text { the } i \text {-industry, where the structural effect of } \\
\text { mutual investment induction takes place as } \\
\text { a result of investment in the } j \text {-industry, to } \\
\text { the change in mutually induced investment } \\
\text { in the inducing } j \text {-industry provoking mutual } \\
\text { investment induction }\end{array}$ \\
\hline
\end{tabular}

Economic substance

A measure of interchangeability of ultimate product and mutually induced investment. It shows how many measurement units of the ultimate product in the $i$-industry, in monetary terms, accounts for a unit of substituted and mutually induced investment in fixed assets of the $j$-industry

$\begin{aligned} & \text { Elasticity of the ultimate } \\ & \text { product structure to } \\ & \text { investment }\end{aligned} \quad E_{i j}^{F U}=-M R I S \cdot \frac{F A_{j}}{F U_{i}}$

The product of the marginal rate of investment substituted and the ratio of the value of fixed assets in the $j$-industry to the ultimate product value in the $i$-industry The relative change in ultimate product in case of structural compensation for mutually induced investment

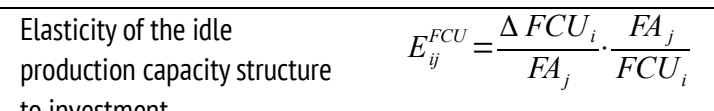
to investment

The product of the ratio of the change in idle production capacity in the $i$-industry due to structural compensation to the change in the amount of fixed assets in the $j$-industry that instigate mutual investment induction and the structural effect and the ratio of the value of fixed assets in the $j$-industry to the value of idle production capacity in the $i$-industry
The relative change in idle production capacity in case of structural compensation of mutually induced investment

The coefficient of investment $\quad K_{I P i j}=\frac{M R I S_{i j}}{F U_{i}} \cdot 100 \%$
pressure on the sectoral
structure of ultimate product
The ratio of the marginal rate of investment substitution to the ultimate product value in the $i$-industry, where the structural effect takes place

$\begin{aligned} & \text { The coefficient of investment } \\ & \text { pressure on the structure of } \\ & \text { idle production capacity }\end{aligned} \quad K_{C U P i j}=\frac{M R I S_{i j}}{F C U_{i}} \cdot 100 \%$
idle production capacity

The ratio of the marginal rate of investment substitution to the value of idle production capacities in the $i$-industry, where the structural effect takes place

$$
K_{I i j}=\frac{M R I S_{i j}}{I_{i}} \cdot 100 \%
$$

The ratio of the marginal rate of investment substitution to the value of the gross product in the $i$-industry, where mutually induced structure of the gross product investment originates

\section{It shows how many percentage points of the ultimate product} output change in the $i$-industry due to the structural effect if a unit cost of mutually induced investment is compensated in the $j$-industry It shows how may percentage points of idle production capacity change in the $i$-industry due to the structural effect if a unit cost of mutually induced investment is incurred in the $j$-industry

\section{It shows how many percentage} points of the gross product output change in $j$-industry due to investment self-induction if a unit cost of mutually induced investment is incurred in the $i$-industry

\begin{tabular}{|c|c|c|}
\hline $\begin{array}{l}\text { The coefficient of investment } \\
\text { pressure on the structure of } \\
\text { production capacity }\end{array}$ & $K_{C U i j}=\frac{M R I S_{i j}}{C U_{i}} \cdot 100 \%$ & $\begin{array}{l}\text { The ratio of the marginal rate of investment } \\
\text { substitution to the value of production } \\
\text { capacities in the } i \text {-industry, where mutually } \\
\text { induced investment originates }\end{array}$ \\
\hline
\end{tabular}

It shows how many percentage points of production capacity change in the $j$-industry due to mutual investment induction if a unit cost of mutually induced investment is incurred in the $i$-industry

Source:Authoring

Please cite this article as: Myakshin V.N. A Study into Structural Effects of Mutual Investment Induction in Sectoral Economic Systems. 
Table 2

Marginal rate of investment substitution for types of economic activities in the USA, 2013

\begin{tabular}{|c|c|c|c|c|c|c|c|c|}
\hline Industry & 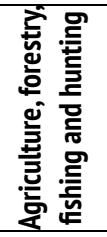 & 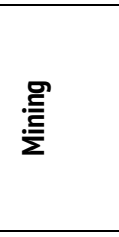 & 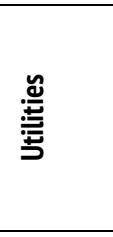 & 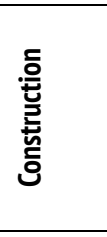 & 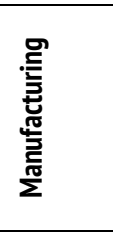 & 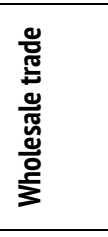 & 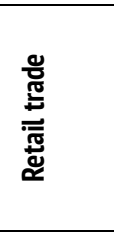 & 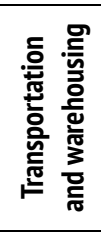 \\
\hline $\begin{array}{l}\text { Agriculture, forestry, fishing } \\
\text { and hunting }\end{array}$ & 0.29152 & 0.00398 & 0.00197 & 0.14689 & 0.20992 & 0.01836 & 0.01183 & 0.02343 \\
\hline Mining & 0.05579 & 0.04555 & 0.02610 & 0.31686 & 0.39162 & 0.03669 & 0.01883 & 0.04825 \\
\hline Utilities & 0.01450 & 0.00292 & 0.00164 & 0.03827 & 0.03355 & 0.01843 & 0.01446 & 0.01134 \\
\hline Construction & 0.01261 & 0.00503 & 0.00270 & 0.02516 & 0.02008 & 0.01728 & 0.01128 & 0.01191 \\
\hline Manufacturing & 0.40553 & 0.06344 & 0.03228 & 2.24229 & 1.32471 & 0.29053 & 0.14473 & 0.38612 \\
\hline Wholesale trade & 0.09785 & 0.01034 & 0.00552 & 0.37891 & 0.20716 & 0.12682 & 0.04368 & 0.06837 \\
\hline Retail trade & 0.00292 & 0.00078 & 0.00055 & 0.38384 & 0.01106 & 0.00557 & 0.00821 & 0.00847 \\
\hline Transportation and warehousing & 0.06003 & 0.01300 & 0.01199 & 0.23185 & 0.13294 & 0.18654 & 0.09535 & 0.14602 \\
\hline Information & 0.01485 & 0.00540 & 0.00287 & 0.11161 & 0.05828 & 0.11050 & 0.05450 & 0.02703 \\
\hline Finance, insurance, real estate, rental and leasing & 0.09835 & 0.02235 & 0.01106 & 0.39791 & 0.15083 & 0.37187 & 0.23542 & 0.13621 \\
\hline Professional and business services & 0.08322 & 0.03975 & 0.01687 & 0.60769 & 0.35880 & 0.60119 & 0.25314 & 0.14500 \\
\hline Educational services, health care and social assistance & 0.00141 & 0.00007 & 0.00010 & 0.00332 & 0.00104 & 0.00316 & 0.00738 & 0.00075 \\
\hline $\begin{array}{l}\text { Arts, entertainment, recreation, accommodation and food } \\
\text { services }\end{array}$ & 0.00693 & 0.00216 & 0.00186 & 0.04317 & 0.02550 & 0.04028 & 0.01665 & 0.01091 \\
\hline Other services, except government & 0.00752 & 0.00153 & 0.00087 & 0.04951 & 0.01982 & 0.05425 & 0.01937 & 0.01106 \\
\hline Government & 0.01821 & 0.00391 & 0.00279 & 0.08010 & 0.05023 & 0.06907 & 0.03010 & 0.05382 \\
\hline
\end{tabular}

Continued from the table above

Industry

\begin{tabular}{|c|c|c|c|c|c|c|c|}
\hline ndustry & 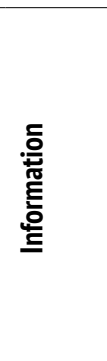 & 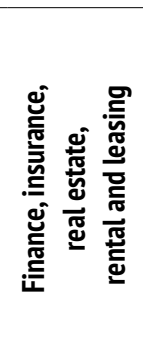 & 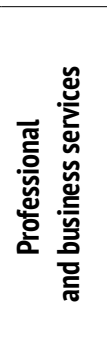 & 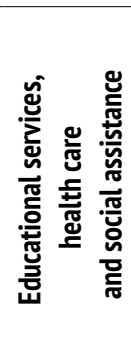 & 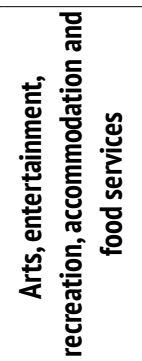 & 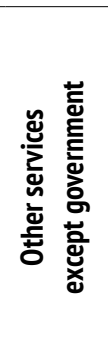 & 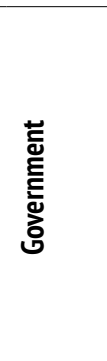 \\
\hline griculture, forestry, fishing and hunting & 0.01056 & 0.00121 & 0.02764 & 0.01703 & 0.03694 & 0.01686 & 0.00476 \\
\hline Aining & 0.02063 & 0.00308 & 0.04994 & 0.03284 & 0.04968 & 0.03410 & 0.01112 \\
\hline tilities & 0.00628 & 0.00458 & 0.01929 & 0.02013 & 0.02020 & 0.01240 & 0.00344 \\
\hline onstruction & 0.00634 & 0.01021 & 0.01749 & 0.01173 & 0.01292 & 0.01613 & 0.00802 \\
\hline Manufacturing & 0.16916 & 0.01859 & 0.39440 & 0.26076 & 0.39545 & 0.27284 & 0.07484 \\
\hline Vholesale trade & 0.03542 & 0.00361 & 0.06611 & 0.04820 & 0.06500 & 0.04359 & 0.01065 \\
\hline etail trade & 0.00185 & 0.00127 & 0.00717 & 0.00379 & 0.01339 & 0.01804 & 0.00092 \\
\hline ransportation and warehousing & 0.02822 & 0.00433 & 0.09034 & 0.03784 & 0.04851 & 0.03205 & 0.01170 \\
\hline nformation & 0.20117 & 0.00915 & 0.16675 & 0.05497 & 0.04987 & 0.04388 & 0.01440 \\
\hline inance, insurance, real estate, rental and leasing & 0.10134 & 0.07114 & 0.44519 & 0.30186 & 0.22001 & 0.25873 & 0.02205 \\
\hline rofessional and business services & 0.17286 & 0.04021 & 0.75918 & 0.25966 & 0.29209 & 0.16978 & 0.04361 \\
\hline $\begin{array}{l}\text { ducational services, health care and social } \\
\text { ssistance }\end{array}$ & 0.00098 & 0.00010 & 0.00179 & 0.01586 & 0.00303 & 0.00491 & 0.00310 \\
\hline
\end{tabular}

Please cite this article as: Myakshin V.N. A Study into Structural Effects of Mutual Investment Induction in Sectoral Economic Systems. 


\begin{tabular}{llllllll}
\hline $\begin{array}{l}\text { Arts, entertainment, recreation, accommodation } \\
\text { and food services }\end{array}$ & 0.03313 & 0.00456 & 0.09035 & 0.03257 & 0.04948 & 0.01672 & 0.00533 \\
\hline Other services, except government & 0.01272 & 0.00307 & 0.04874 & 0.03163 & 0.02427 & 0.01991 & 0.00399 \\
\hline Government & 0.02381 & 0.00653 & 0.05457 & 0.02780 & 0.03561 & 0.02981 & 0.00664 \\
\hline
\end{tabular}

Source:Authoring

Table 3

Full value of integral coefficients of integral self-induction in line with the structural effect calculated on the basis of the cross-sectoral balance of the USA, 1997-2013

\begin{tabular}{|c|c|c|c|c|c|c|c|c|c|}
\hline Industry & 1997 & 1998 & 1999 & 2000 & 2001 & 2002 & 2003 & 2004 & 2005 \\
\hline Agriculture, forestry, fishing and hunting & 0.688 & 0.690 & 0.700 & 0.662 & 0.727 & 0.722 & 0.681 & 0.650 & 0.644 \\
\hline Mining & 0.271 & 0.249 & 0.271 & 0.329 & 0.263 & 0.201 & 0.200 & 0.185 & 0.180 \\
\hline Utilities & 0.239 & 0.273 & 0.323 & 0.421 & 0.555 & 0.341 & 0.374 & 0.343 & 0.465 \\
\hline Construction & 5.794 & 5.578 & 5.406 & 5.442 & 5.758 & 5.718 & 5.874 & 6.066 & 6.399 \\
\hline Manufacturing & 1.144 & 1.090 & 1.123 & 1.193 & 1.205 & 1.236 & 1.214 & 1.275 & 1.437 \\
\hline Wholesale trade & 1.623 & 1.434 & 1.580 & 1.619 & 1.542 & 1.723 & 1.732 & 1.924 & 2.068 \\
\hline Retail trade & 1.264 & 1.100 & 1.186 & 1.148 & 1.038 & 1.078 & 1.133 & 1.240 & 1.200 \\
\hline Transportation and warehousing & 0.708 & 0.677 & 0.683 & 0.745 & 0.700 & 0.695 & 0.760 & 0.863 & 0.939 \\
\hline Information & 0.461 & 0.480 & 0.504 & 0.615 & 0.580 & 0.524 & 0.530 & 0.504 & 0.532 \\
\hline Finance, insurance, real estate, rental and leasing & 0.062 & 0.065 & 0.068 & 0.075 & 0.067 & 0.062 & 0.063 & 0.070 & 0.074 \\
\hline Professional and business services & 1.760 & 1.823 & 1.819 & 1.834 & 1.806 & 1.680 & 1.756 & 1.848 & 1.978 \\
\hline Educational services, health care and social assistance & 1.117 & 1.161 & 1.154 & 1.205 & 1.308 & 1.356 & 1.378 & 1.352 & 1.388 \\
\hline Arts, entertainment, recreation, accommodation and food services & 1.373 & 1.321 & 1.298 & 1.323 & 1.313 & 1.248 & 1.277 & 1.340 & 1.407 \\
\hline Other services, except government & 1.178 & 1.226 & 1.202 & 1.167 & 1.384 & 1.331 & 1.389 & 1.380 & 1.315 \\
\hline Government & 0.168 & 0.169 & 0.174 & 0.182 & 0.201 & 0.209 & 0.217 & 0.213 & 0.216 \\
\hline \multicolumn{10}{|l|}{ Continued from the table above } \\
\hline Industry & & 2006 & 2007 & 2008 & 2009 & 2010 & 2011 & 2012 & 2013 \\
\hline Agriculture, forestry, fishing and hunting & & 0.613 & 0.707 & 0.794 & 0.730 & 0.688 & 0.715 & 0.739 & 0.688 \\
\hline Mining & & 0.160 & 0.133 & 0.135 & 0.079 & 0.109 & 0.128 & 0.137 & 0.140 \\
\hline Utilities & & 0.386 & 0.366 & 0.389 & 0.222 & 0.226 & 0.163 & 0.127 & 0.137 \\
\hline Construction & & 6.203 & 5.491 & 5.236 & 4.697 & 4.212 & 3.968 & 4.014 & 4.117 \\
\hline Manufacturing & & 1.480 & 1.462 & 1.500 & 1.251 & 1.337 & 1.372 & 1.364 & 1.351 \\
\hline Wholesale trade & & 2.070 & 2.123 & 2.071 & 1.267 & 1.778 & 1.925 & 1.898 & 1.918 \\
\hline Retail trade & & 1.195 & 1.165 & 1.022 & 0.934 & 1.105 & 1.078 & 1.126 & 1.165 \\
\hline Transportation and warehousing & & 1.022 & 1.038 & 1.095 & 0.954 & 0.924 & 0.953 & 0.898 & 0.873 \\
\hline Information & & 0.550 & 0.513 & 0.490 & 0.476 & 0.447 & 0.467 & 0.502 & 0.511 \\
\hline Finance, insurance, real estate, rental and leasing & & 0.074 & 0.074 & 0.082 & 0.071 & 0.079 & 0.077 & 0.072 & 0.070 \\
\hline Professional and business services & & 1.997 & 1.998 & 1.819 & 1.729 & 1.814 & 1.780 & 1.773 & 1.785 \\
\hline Educational services, health care and social assistance & & 1.352 & 1.334 & 1.290 & 1.352 & 1.367 & 1.347 & 1.391 & 1.407 \\
\hline Arts, entertainment, recreation, accommodation and food services & & 1.403 & 1.380 & 1.310 & 1.166 & 1.228 & 1.284 & 1.274 & 1.301 \\
\hline Other services, except government & & 1.331 & 1.307 & 1.310 & 1.221 & 1.256 & 1.235 & 1.257 & 1.221 \\
\hline Government & & 0.212 & 0.206 & 0.216 & 0.219 & 0.212 & 0.194 & 0.189 & 0.184 \\
\hline
\end{tabular}

Source: Authoring

Please cite this article as: Myakshin V.N.A Study into Structural Effects of Mutual Investment Induction in Sectoral Economic Systems. 


\section{Acknowledgments}

The article was supported by the Russian Foundation for Humanities, project No. 16-12-29004.

\section{References}

1. Petrov V.N. [Political economy and forest economics of Russia]. Izvestiya Sankt-Peterburgskoi lesotekhnicheskoi akademii = Bulletin of Saint Petersburg Forest Technical Academy, 2010, no. 193, pp. 288-307. (In Russ.)

2. Petrov V.N., Tyurin A.E. [The evaluation of ecological interests balance in forest relations]. Lesnoi vestnik = Forestry Bulletin, 2010, no. 2, pp. 142-147. (In Russ.)

3. Stepanova V.V. [Investment attractiveness of the Pomorye region of Russia]. Ekonomika i upravlenie Rossiiskii nauchnyi zhurnal = Economics and Management Russian Scientific Journal, 2007, no. 9, pp. 76-80. (In Russ.)

4. Miller R.E., Blair P.D. Input-Output Analysis: Foundations and Extensions. New York, Cambridge University Press, 2009, $750 \mathrm{p}$.

5. Davydov A. [Structural changes in US economy]. Mirovaya ekonomika i mezhdunarodnye otnosheniya $=$ World Economy and International Relations, 2009, no. 11, pp. 35-47. (In Russ.)

6. Structural Dynamics and Economic Growth. Cambridge University Press, 2011, 296 p.

7. Hirschman A. Strategy of Economic Development. New York, Norton, 1978, 217 p.

8. Bai J., Perron P. Estimating and Testing Linear Models with Multiple Structural Changes. Econometrica, 1998, vol. 66, iss. 1, pp. 47-78. URL: http://dx.doi.org/10.2307/2998540

9. Sonis M., Hewings G.J.D., Sulistyowati S. Block Structural Path Analysis: Applications to Structural Changes in the Indonesian Economy. Economic Systems Research, 1997, vol. 9, iss. 3, pp. 265-280.

URL: http://dx.doi.org/10.1080/09535319700000020

10. Myakshin V.N. Strukturnye preobrazovaniya v promyshlennosti na osnove mezhotraslevykh investitsionnykh vzaimodeistvii: monografiya [Structural transformations in the industrial sector through cross-sectoral investment interactions: a monograph]. Arkhangelsk, AO IOO Publ., 2015, 200 p.

11. Domar E. Essays in the Theory of Economic Growth. Oxford University Press, 1982, 272 p.

12. Leontieff W. Izbrannye proizveniya: $v 3$ t. T. 1: Obshcheekonomicheskie problemy mezhotraslevogo analiza [Selected works: Three volumes. Volume 1: General economic aspects of cross-sectoral analysis]. Moscow, Ekonomika Publ., 2006, 407 p.

13. Aganbegyan A.G. Sotsial'no-ekonomicheskoe razvitie Rossii [Socio-economic development of Russia]. Moscow, Delo Publ., 2005, $270 \mathrm{p}$.

14. Jones C.I. Misallocation, Economic Growth, and Input-Output Economics. NBER Working Paper, 2011, no. 16742, $48 \mathrm{p}$.

15. Meyer D. R. Structural Changes in the Economy of Hong Kong since 1997. The China Review, 2008, vol. 8, iss. 1, pp. 7-29.

16. Greenwood J., Hercowitz Z., Huffman G.W. Investment, Capacity Utilization, and the Real Business Cycle. The American Economic Review, 1988, vol. 78, iss. 3, pp. 402-417.

17. Hayek F.A. The Fatal Conceit: The Errors of Socialism. University of Chicago Press, 2011.

18. De Soto J.H. Socialism, Economic Calculation and Entrepreneurship. Edward Elgar, 2010, 320 p.

Please cite this article as: Myakshin V.N. A Study into Structural Effects of Mutual Investment Induction in Sectoral Economic Systems. 
19. Hoekstra R., Van Den Bergh J.C.J.M. Structural Decomposition Analysis of Physical Flows in the Economy. Environmental and Resource Economics, 2002, vol. 23, iss. 3, pp. 357-378. URL: http://dx.doi.org/10.1023/A:1021234216845

20. Holz C.A. The Unbalanced Growth Hypothesis and the Role of the State: The Case of China's State-Owned Enterprises. Journal of Development Economics, 2011, vol. 96, iss. 2, pp. 220-238.

URL: http://doi.org/10.1016/j.jdeveco.2010.10.007

\section{Conflict-of-interest notification}

I, the author of this article, bindingly and explicitly declare of the partial and total lack of actual or potential conflict of interest with any other third party whatsoever, which may arise as a result of the publication of this article. This statement relates to the study, data collection and interpretation, writing and preparation of the article, and the decision to submit the manuscript for publication. 